\title{
Stage 0 Esophageal Cancer AJCC v7
}

National Cancer Institute

\section{Source}

National Cancer Institute. Stage O Esophageal Cancer A/CC v7. NCI Thesaurus. Code C89771.

Stage 0 includes: For squamous cell carcinoma: T is (HGD), N0, M0, G1, GX, T umor location: Any. For adenocarcinoma: T is (HGD), N0, M0, G1, GX. T is: High-grade dysplasia. N0: No regional lymph node metastasis. M0: No distant metastasis. G1: Well differentiated. GX: Grade cannot be assessed-stage grouping as G1. Tumor location: Location of the primary cancer site is defined by the position of the upper (proximal) edge of the tumor in the esophagus. (AJCC 7th ed.) 